\title{
Colombian vs. American corn: Quality, chemical composition, mycotoxin content and metabolizable energy
}

\author{
Maiz colombiano vs. estadounidense: Calidad, composición química, contenido de micotoxinas y energía \\ metabolizable
}

\author{
Milho colombiano vs. Americano: Qualidade, composição química, teor de micotoxinas e energia \\ metabolizável
}

Yandy J Aguillón-Páez* (D); Liliana Betancourt (D); Gonzalo J Díaz (D).

Facultad de Medicina Veterinaria y de Zootecnia, Universidad Nacional de Colombia, Bogotá, 111321, Colombia.

To cite this article:

Aguillón-Páez YJ, Betancourt L, Díaz GJ. Colombian vs. American corn: Quality, chemical composition, mycotoxin content and metabolizable energy. Rev Colomb Cienc Pecu 2022; 35(1): 36-48. DOI: https://doi.org/10.17533/udea.rccp.v35n1a04

\begin{abstract}
Background: Corn is, quantitatively, one of the most important world crops (ranking second only after wheat) and a key ingredient in animal feeds. Objective: to assess and compare corn quality, mycotoxin content, chemical composition and apparent metabolizable energy (AME) of domestic and imported corn. Methods: Grain quality (USDA grading system) was determined in 30 samples of domestic and 21 samples of imported corn. From each origin, 15 samples were subjected to proximal analysis and 10 were used to determine fatty acid composition. Mycotoxin analysis was conducted on 30 samples of domestic and 23 of imported corn. Results: six of the 30 domestic samples corresponded to US1 grade (highest quality) vs. none of the imported. In the "sample grade" category (lowest quality), 10 and 6 samples corresponded to imported and domestic corn, respectively. Soybeans were found as contaminant in 15 of the 21 imported corn samples. Aspergillus spp. mycotoxins such as ochratoxin A were not detected, and aflatoxins were found in only a few samples at very low levels. Fusariotoxins such as deoxynivalenol and zearalenone were found in 61 and $43 \%$ of imported samples, respectively, but in none of the domestic samples. Domestic corn had lower carbohydrate content compared with imported corn (85.4 vs. $86.7 \%)$, but higher crude fat (3.8 vs. 3.1\%). The AME values for domestic and imported corn were 3,697 and 3,378 kcal/kg, respectively. The fatty acid profiles from both corn types were similar. Conclusion: This study found significant differences between locally-grown and imported corn, particularly in terms of crude fat, AME content, fusariotoxins, and contaminant seeds (soybeans). These findings suggest that locally-grown corn might have nutritional and toxicological advantages over corn imported from the United States.
\end{abstract}

Received: April 24, 2020; accepted: April 16, 2021

*Corresponding author. Carrera 30 \# 45-03 Edificio de Posgrados Medicina Veterinaria y Zootecnia 561B, Laboratorio de Toxicología. Tel: +57 (1) 316-5630 E-mail: yaguillon@unal.edu.co 
Keywords: animal feed; apparent metabolizable energy; broiler chickens; chemical composition; corn kernel quality; Colombian corn; fungal toxins; grain quality; corn; mycotoxins; nutritional value; US corn; Zea mays.

\section{Resumen}

Antecedentes: El maíz es, cuantitativamente, uno de los cultivos más importantes a nivel mundial (ocupa el segundo lugar después del trigo) y uno de los principales ingredientes en dietas para animales. Objetivo: Evaluar y comparar la calidad del maíz, su contenido de micotoxinas, composición química, y energía metabolizable aparente (AME) del maíz nacional e importado. Métodos: La calidad del grano (sistema de clasificación de la USDA) se determinó en 30 muestras de maíz producido en Colombia y 21 de maíz importado. De cada origen, 15 muestras se sometieron a análisis proximal y 10 se analizaron para determinar el perfil de ácidos grasos. El contenido de micotoxinas se determinó en 30 muestras de maíz nacional y 23 de maíz importado. Resultados: Seis de las treinta muestras nacionales analizadas para calidad de grano correspondieron a grado US1 (la mejor calidad) frente a ninguna de las importadas. En categoría "grado muestra" (la menor calidad) se encontraron 10 y 6 de las muestras de maíz importado y nacional, respectivamente; 15 de las 21 muestras de maíz importado presentaron contaminación con semillas de fríjol soya. No se encontraron micotoxinas de hongos Aspergillus spp. (ocratoxina A), y niveles muy bajos de aflatoxinas en unas pocas muestras. Fusariotoxinas tales como deoxinivalenol y zearalenona se detectaron en el 61 y $43 \%$ de las muestras de maíz importado, respectivamente, pero en ninguna muestra de maíz nacional. El maíz nacional presentó menor contenido de carbohidratos $(85,4$ vs. $86,7 \%)$, pero mayor contenido de grasa cruda $(3,8$ vs. $3,1 \%)$ en comparación con el importado, respectivamente. Los valores de AME fueron de 3.697 y $3.378 \mathrm{kcal} / \mathrm{kg}$ para el maíz nacional e importado, respectivamente. El perfil de ácidos grasos de ambas procedencias fue similar. Conclusiones: Este estudio encontró diferencias significativas entre el maíz de producción nacional y el importado, en especial en su contenido de grasa cruda y AME, fusariotoxinas, y semillas contaminates (soya). Estos hallazgos sugieren que el maíz de producción nacional puede presentar ventajas de tipo nutricional y toxicológico frente al maíz importado de los Estados Unidos de América.

Palabras clave: alimento animal; calidad del grano; calidad del grano de maiz; composición química; energía metabolizable aparente; maiz; maíz colombiano; maíz estadounidense; micotoxinas; pollos de engorde; toxinas fúngicas; valor nutricional; Zea $\underline{\text { mays. }}$.

\section{Resumo}

Antecedentes: O milho é quantitativamente uma das culturas mais importantes em nível mundial (ocupando o segundo lugar depois do trigo), sendo um dos principais ingredientes em dietas para animais. Objetivo: Avaliar e comparar a qualidade do milho, o teor de micotoxinas, a composição química e a energia metabolizável aparente (EMA) do milho nacional e importado. Métodos: A qualidade do grão (sistema de classificação do USDA) foi determinada em 30 amostras de milho produzido na Colômbia e 21 amostras de milho importado. Quinze amostras de cada tipo de milho foram submetidas a análise proximal e dez amostras de cada milho foram analisadas para determinar o perfil de ácidos graxos. O conteúdo de micotoxinas foi determinado em 30 amostras de milho da Colômbia e em 23 amostras de milho importado. Resultados: Seis das trinta amostras colombianas analisadas para qualidade de grão corresponderam a grau US1 (melhor qualidade) frente a nenhuma das amostras importadas. Na categoria "grau amostra" (menor qualidade) foram encontradas 10 e 6 amostras de milhos importados e colombianos, respectivamente; Quinze das 21 amostras de milho importado apresentaram contaminação com sementes de feijão soja. Não foram encontradas micotoxinas de fungos Aspergillus spp. (ocratoxina A) ou apenas níveis muito baixos em poucas amostras (aflatoxinas). As fusariotoxinas, deoxinivalenol e zearalenona foram detectadas em $61 \mathrm{e} 43 \%$ das amostras de milho importado, respectivamente, mas não foram detectadas em nenhuma amostra do milho colombiano. $\mathrm{O}$ milho colombiano apresentou menor conteúdo de carboidratos ( 85,4 vs. $86,7 \%$ ) porém maior conteúdo de gordura crua (3,8 vs. $3,1 \%)$. Os valores de AME foram 3.697 e $3.378 \mathrm{kcal} / \mathrm{kg}$ para as amostras de milho colombiano e importado, respectivamente. O perfil de ácidos graxos de ambos tipos de milho foi similar. Conclusões: Os resultados do presente estudo mostram diferenças significativas entre o milho de origem colombiana e o milho importado dos Estados Unidos, em especial no conteúdo de gordura crua e AME, fusariotoxinas e sementes contaminantes (soja). Estes achados sugerem que o milho de produção colombiana pode apresentar vantagens de tipo nutricional e toxicológica frente ao milho importado dos Estados Unidos.

Palavras-chave: alimentação animal; composição química; energia metabolizável aparente; frangos de corte; micotoxinas; milho; milho colombiano; milho dos EUA; qualidade dos grãos; qualidade do grãos de milho; toxinas fúngicas; valor nutricional; $\underline{\text { Zea }} \underline{\text { mays. }}$. 


\section{Introduction}

The Colombian poultry agribusiness depends almost entirely on imported corn for the production of complete feeds. Corn is, quantitatively, the major ingredient in poultry diets, with inclusion levels up to $50-60 \%$. Therefore, corn quality has a significant impact on the health and performance of poultry. According to the United States Department of Agriculture (USDA), the expected global production of corn for 2019-2020 is estimated at 1.019 million tonnes (Micolucci, 2019). The United States is the largest world producer with slightly more than 347 million tonnes estimated for 2019-2020 (Micolucci, 2019). The annual corn production in Colombia is very low (about 1.5 million tons), and far from the demand of approximately 7 million tonnes (Fenalce, 2019). This high demand compared with the low local production results in the need for animal feed producers to import corn, mostly from the United States. Transport of corn to local feed mills involves long journey distances and long storage times that create a risk for grain quality deterioration and contamination. It has been reported that each time a lot of corn is handled during transport, both the percentages of broken grains and dust formation increase (Györi, 2017; Hernández et al., 2009). Further, a common issue that may impair grain quality and safety is fungal contamination of corn, both during field growth and after harvest. Fungal growth may result in the production of potentially toxic compounds (mycotoxins), which, depending on their concentration, might cause adverse effects on poultry (Diaz, 2020). Another unfavourable effect of fungal contamination is nutritional deterioration of the grain caused by fungal growth, which leads to decreased fat, carbohydrate, vitamin and protein content of the kernel. The adverse effects of fungi on nutrient composition is particularly severe on crude fat and energy contents, which results in poor bird performance (Diaz, 2020). This effect is attributed to fungal lipases, which hydrolyze triglycerides to free fatty acids, which are, in turn, used as energy source by the microorganism (Diaz, 2020; Christensen and Kaufman, 1965).
Additionally, importation of large quantities of corn puts domestic producers at risk. Policies should be established to help local corn growers become more productive and competitive. A government stimulus of corn production in Colombia could represent several advantages, including reduced transport and storage times, which in turn could reduce grain deterioration and contamination.

No studies have been conducted comparing Colombian-produced corn vs. corn imported from the USA. Therefore, the objective of the present study was to assess and compare corn quality, mycotoxin content, chemical composition and apparent metabolizable energy (AME) of domestic and imported corn.

\section{Materials and Methods}

\section{Ethical considerations}

The broiler chicken experiment was approved by the Ethics Committee of Facultad de Medicina veterinaria $y$ de Zootecnia of Universidad Nacional de Colombia, Bogota (Colombia), under approval No. CB-FMVZUN-010-19.

\section{Location of the study}

Chemical analyses were carried out at the Toxicology and Animal Nutrition laboratories of the Facultad de Medicina veterinaria $y$ de Zootecnia of Universidad Nacional de Colombia, Bogota, Colombia. The broiler chicken trial was carried out at the poultry research facilities of the same university.

\section{Samples}

Sampling was carried out by the "Federación Nacional de Cultivadores de Cereales y Leguminosas" (FENALCE). Samples of imported corn were collected at two of the major Colombian sea ports (Buenaventura and Santa Marta) over a one-year period. Precise collection instructions for each sample included a minimum of ten sampling points, with each subsample of $500 \mathrm{~g}$, for a total of minimum 
$5 \mathrm{~kg}$. Colombian corn samples were collected in the same way in Valle del Cauca and Tolima Provinces. Samples were packed in paper bags to prevent moisture condensation and sent to the laboratory immediately after collection. The corn hybrids grown in Colombia and analyzed in the present study were LEPTRA P30F35, ADVANTA 9293, PIONER 7088, SV 1035, and DOW 810. It was not possible to trace the variety of corn imported from the United States.

\section{Corn kernel quality}

The percentages of broken kernels and impurities were determined in 30 samples of locally-grown corn and 21 of imported corn. For this purpose, a $1 \mathrm{~kg}$ sample was sieved through 4,76 $\mathrm{mm}$ (mesh 4) and 2,38 $\mathrm{mm}$ (mesh 8) sieves, as previously described (Hernández et al., 2009; CIMMYT, 2016). The quality classification was based on the guidelines described in the "Official United States Standards for Grain" of the USDA-GIPSA (1996). Under this classification, percentages of impurities plus broken grains corresponding to $<2,<3,<4,<5$, and $7 \%$ are assigned to grades US1, US2, US3, US4, US5, respectively. Grains that do not meet any of these criteria are classified as SG ("sample grade").

\section{Proximal analysis}

In order to compare the basic composition of local and imported corn, 15 samples of each type of corn were randomly selected and subjected to proximal analysis [dry matter (Method 2001.12), ash content (Method 935.12), crude protein (Method 968.06), crude fat (Method 920.39), and crude fiber (Method 962.09)] according to the methods described by the AOAC (Association of Official Analytical Chemists International, 2006). The nitrogenfree extract content was calculated from data obtained in the proximal analysis.

\section{Mycotoxin analysis}

The following mycotoxins were determined using high-performance liquid chromatography (HPLC) in the 30 samples of local and 23 of imported corn, using the Colombian Technical
Standards (NTC, Norma Técnica Colombiana): aflatoxins B1, B2, G1, and G2 (NTC 1232, 1996); ochratoxin A (NTC 5472, 2007), zearalenone (NTC 4881, 2000), T-2, and HT-2 toxins (NTC 6027, 2013), and deoxynivalenol (NTC 5961, 2012). These analyses were conducted on a Shimadzu Prominence system (Shimadzu Scientific Instruments, Columbia, MD, USA) equipped with a DGU-20A3R degassing unit, two LC-20AD pumps, a SIL-20ACHT autosampler, a CTO-20A column oven, an RF20AXS fluorescence detector, an SPD-20AV visible-ultraviolet spectrophotometric detector and a CBM-20A bus module, all controlled by "LC Solutions" software. Fumonisins B1, B2, and B3 were analyzed by HPLC-tandem mass spectrometry (LC-MS/MS) according to the method described by Martos et al. (2010).

\section{Determination of the fatty acid profile}

Ten random samples each of local and imported corn were analyzed for fatty acid composition. Corn kernel oil was extracted by shaking finely ground kernel samples with diethyl ether for 12 hours. The percentage of fatty acids was determined by gas chromatography according to the method described by Aguillón-Páez et al. (2020). About $20 \mu \mathrm{L}$ of the ether extract (containing about 2 mg corn oil) were added to $160 \mu \mathrm{L}$ toluene and $20 \mu \mathrm{L}$ Meth-Prep II transesterification reagent (Alltech Associates, Inc., Deerfield, IL, USA). The mix was left at room temperature for $30 \mathrm{~min}$ and then $1 \mu \mathrm{L}$ of the solution was injected into the gas chromatograph for determination of fatty acid methyl esters (FAME). The FAME were separated on a $30 \mathrm{~m} \times 0.32 \mathrm{~mm}$ inside diameter $\times 0.25 \mu \mathrm{m}$ film thickness SGE BPX70 capillary column (SGE Analytical Science, Australia) using a Shimadzu GC-2014 Gas Chromatograph (Shimadzu Scientific Instruments, Columbia, MD, USA) equipped with a flame ionization detector. Separation was obtained with a temperature ramp (initial temperature $80{ }^{\circ} \mathrm{C}$ for $2 \mathrm{~min}, 30^{\circ} \mathrm{C} / \mathrm{min}$ until $140^{\circ} \mathrm{C}$, then $10 \mathrm{~min}$ at $140^{\circ} \mathrm{C}, 2.9^{\circ} \mathrm{C} / \mathrm{min}$ to $200^{\circ} \mathrm{C}$, and finally $9 \mathrm{~min}$ at $200^{\circ} \mathrm{C}$ ) using helium as the carrier gas and nitrogen as the make-up gas. The injection was made in split mode with a split ratio of 1:30. Retention times were compared with 
those of known standards (37 component FAME mix, Merck KGaA, Darmstadt, Germany).

\section{Apparent metabolizable energy}

The apparent metabolizable energy (AME) of one random sample of locally-grown corn and one random sample of imported corn was determined in a trial conducted with 180 oneday-old male chicks from the Ross 308 AP strain. The chicks were randomly distributed in three experimental groups. Each group was replicated 6 times, with 10 birds per replicate pen. The experimental treatments corresponded to three different diets provided ad libitum from days 1 to 21 of age, as follows. Diet 1: reference diet (starch-based); diet 2: 60\% reference diet $+40 \%$ locally-grown corn; and diet 3: 60\% reference diet $+40 \%$ imported corn. The reference diet reached or exceeded the nutritional requirements of broiler chickens (NRC,1994) (Table 1).

Table 1. Composition of the reference diet.

\begin{tabular}{|c|c|}
\hline Ingredientes \% & Reference diet (starch-based) \\
\hline Starch & 45.6 \\
\hline Soybean meal & 32.1 \\
\hline Full-fat soybean & 10.0 \\
\hline Fish meal & 8.0 \\
\hline Vegetable oil & 1.26 \\
\hline Sodium chloride & 0.30 \\
\hline Calcium carbonate & 0.45 \\
\hline Calcium phosphate & 0.80 \\
\hline Bicarbonate & 0.30 \\
\hline Vitamin mix* & 0.05 \\
\hline Mineral mix* & 0.05 \\
\hline Choline & 0.10 \\
\hline Methionine & 0.32 \\
\hline Threonine & 0.03 \\
\hline Chromium oxide & 0.50 \\
\hline \multicolumn{2}{|l|}{ Calculated analyses (\%) } \\
\hline Metabolizable energy $(\mathrm{kcal} / \mathrm{kg})$ & 3,224 \\
\hline Crude protein & 25 \\
\hline Crude fat & 5.21 \\
\hline Crude fiber & 2.65 \\
\hline Linoleic acid & 1.29 \\
\hline$\alpha$-linolenic acid & 0.20 \\
\hline Calcium & 0.80 \\
\hline Total phosphorus & 0.64 \\
\hline Available phosphorus & 0.37 \\
\hline Digestible lysine & 1.79 \\
\hline Digestible methionine & 0.59 \\
\hline Digestible threonine & 1.07 \\
\hline Digestible tryptophan & 0.33 \\
\hline Digestible methionine + cysteine & 0.89 \\
\hline
\end{tabular}

*Vitamin-mineral mix. Contet per kg: zinc 20,000 mg; iron: 8,400 mg; manganese: 35,000 mg; copper: 1,700 mg; iodo: 430 mg; selenium: $60 \mathrm{mg}$; vitamin A: 344,000 UI; vitamin D3: 680,000 UI; vitamin E: 4,000 UI; choline: 172,000 mg; niacin: 9,000 mg; calcium pantotheate: 3,060 mg; vitamin B2: 1,430 mg; vitamin B2: 1,430 mg; vitamin K3: $856 \mathrm{mg}$; vitamin B12: $4.6 \mathrm{mg}$. 
The AME values were determined according to the methods described by Sakomura and Rostagno (2016) using chromium oxide (III) as a marker $\left(\mathrm{Cr}_{2} \mathrm{O}_{3}\right)$. Feed and excreta were collected on days 19, 20 and 21 for gross energy (GE) and chromium content determination. Excreta were collected in the morning and the afternoon, cleaned of feathers and any other extraneous material, placed in aluminum trays and dried in a forced ventilation oven at $55^{\circ} \mathrm{C}$ for $72 \mathrm{~h}$ (Sakomura and Rostagno, 2016). The GE was measured with an adiabatic calorimeter (Parr 6200, Parr Instrument Company, Moline, Illinois, USA) calibrated with benzoic acid with a known caloric value (26.4 $\mathrm{MJ} / \mathrm{kg}$ ). Chromium content was determined by atomic absorption spectrophometry as described by Williams et al. (1962).

The AME was calculated using the following equations:

- Indigestibility factor (IF) $=$

$\frac{\% \text { of marker in test diet }}{\% \text { of marker in excreta }}$

- AME of experimental diets $=(\mathrm{GE}$ of diet $)-$ (GE of excreta * IF)

- AME test corn $=$

(AME reference diet) + AME test diet - AME reference diet

0.4

\section{Statistical analysis}

Depending on the variables measured, mean values were compared using a $t$-test for independent samples or analysis of variance. Homogeneity of variances was determined by the Levene test. Statistical analyses were carried out using the STATISTIX version 9 program (Statistix, 2008), with a significance level of 0.05 .

\section{Results}

\section{Corn kernel quality}

Twenty percent (6/30) of the locally-grown corn samples were classified as US1, while none of the imported corn samples $(0 / 21)$ fell into this category (Figure 1). Further, 13\% (4/30) of the locally-produced corn samples were classified as US2 grain compared to $5 \%(1 / 21)$ of the imported grain. A total of 10 out of the 21 samples of imported corn (48\%) fell into grades US3 to US5, whereas the remaining 10 samples (48\%) were classified as SG. In the case of the locallyproduced corn, 14 out of 30 samples (47\%) corresponded to US3-US5 grades, with only 6 out of $30(20 \%)$ falling into the SG category (Figure 1). Interestingly, soybean kernels were found in 15 of the 21 samples of imported corn, but in none of the domestic corn samples.

\section{Number of samples in each US grade}

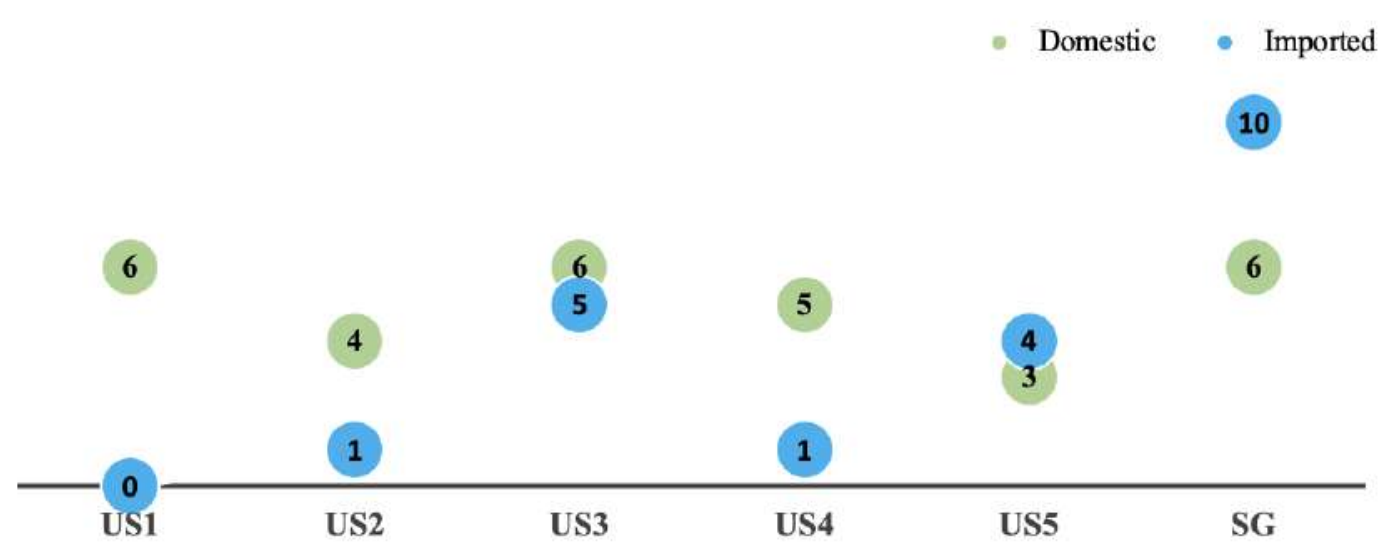

Figure 1. Locally-grown and imported corn samples classified into US grades according to their content of broken kernels and impurities. 
Proximal analysis results of 15 samples of each corn source are summarized in Table 2. Significant differences were found for dry matter, ash, and nitrogen-free extract of local and imported corn.

Table 3 summarizes the apparent metabolizable energy (AME) results calculated for one sample of locally-grown corn and one of imported corn. The AME values (on a dry-matter basis) for the local and imported corn were significantly different.

Table 4 shows the average percent fatty acid composition of the 10 samples analyzed for each type of corn. With the exception of palmitoleic acid (C16:1), the percentage of all fatty acids differed significantly $(p<0.05)$. The content of monounsaturated fatty acids (MUFAS), polyunsaturated (PUFAS), saturated (SFAS), n-3, n-6 and the ratio n-6/n-3 also differed significantly $(p<0.05)$. The fatty acid found in highest concentration in both domestic and imported corn was linoleic acid (C18:2, n-6), followed by oleic, palmitic and stearic acids. The other fatty acids were found in percentages close to $1 \%$ or lower, including the only omega-3 fatty acid present in corn oil (C18:3, n-3).

Table 2. Proximal analysis (\%) of domestic and imported corn samples (on a dry-matter basis).

\begin{tabular}{ccccccc}
\hline & Dry matter & $\begin{array}{c}\text { Crude } \\
\text { protein }\end{array}$ & Ash & Crude fat & Crude fiber & NFE \\
\hline Domestic & $88.0 \pm 0.2^{\mathrm{a}}$ & $7.6 \pm 0.3^{\mathrm{a}}$ & $1.2 \pm 0.1^{\mathrm{a}}$ & $3.8 \pm 0.3^{\mathrm{a}}$ & $2.0 \pm 0.1^{\mathrm{a}}$ & $85.4 \pm 0.4^{\mathrm{b}}$ \\
Imported & $86.7 \pm 0.2^{\mathrm{b}}$ & $7.5 \pm 0.2^{\mathrm{a}}$ & $1.0 \pm 0.0^{\mathrm{b}}$ & $3.1 \pm 0.3^{\mathrm{a}}$ & $1.7 \pm 0.1^{\mathrm{a}}$ & $86.7 \pm 0.3^{\mathrm{a}}$ \\
p-value & $<0.001$ & 0.822 & 0.011 & 0.101 & 0.146 & 0.010 \\
\hline
\end{tabular}

Values are means \pm SEM of 15 samples. Different superscripts letters $\left({ }^{a}, b\right)$ within columns indicate significant difference $(\mathrm{p}<0.05)$. NFE: nitrogen-free extract.

Table 3. Apparent metabolizable energy (AME) for broiler chickens of a locally-grown corn sample and an imported corn sample, measured using chromium oxide $\left(\mathrm{Cr}_{2} \mathrm{O}_{3}\right)$ as a marker.

\begin{tabular}{|c|c|c|c|c|}
\hline \multirow{2}{*}{ Results as dry matter (DM) } & \multicolumn{4}{|c|}{ Experimental diets } \\
\hline & Starch-based & Locally-grown corn & Imported corn & p-value \\
\hline \multicolumn{5}{|l|}{ DIETS } \\
\hline Dry matter (g/kg diet) & 902.7 & 896.9 & 896.2 & - \\
\hline Gross energy (kcal/kg) & 4,440 & 4,380 & 4,350 & - \\
\hline Chromium content $(\mathrm{g} / \mathrm{kg})$ & 4.8 & 4.6 & 5.3 & - \\
\hline \multicolumn{5}{|l|}{ EXCRETA } \\
\hline Dry matter (g/kg excreta) & $927.8 \pm 0.29$ & $932.9 \pm 0.13$ & $926.3 \pm 0.08$ & 0.007 \\
\hline Gross energy $(\mathrm{kcal} / \mathrm{kg})$ & $3,547 \pm 34.8^{b}$ & $3,808 \pm 29.2^{\mathrm{a}}$ & $3,825 \pm 19.8^{\mathrm{a}}$ & $<0.001$ \\
\hline Chromium content (g/kg) & $14.8 \pm 0.43^{b}$ & $18.9 \pm 0.63^{\mathrm{a}}$ & $19.7 \pm 0.29^{\mathrm{a}}$ & $<0.001$ \\
\hline Indigestibility factor & $0.327 \pm 0.01^{b}$ & $0.245 \pm 0.01^{\mathrm{a}}$ & $0.269 \pm 0.01^{\mathrm{a}}$ & $<0.001$ \\
\hline Diet AME (kcal/kg) & $3,282 \pm 33.3^{b}$ & $3,448 \pm 28.0^{\mathrm{a}}$ & $3,321 \pm 13.1^{b}$ & 0.001 \\
\hline Corn AME (kcal/kg DM) & & $3,697 \pm 70.1^{\mathrm{a}}$ & $3,378 \pm 32.8^{\mathrm{b}}$ & 0.002 \\
\hline
\end{tabular}

Values are means \pm SEM of 6 replicate pens per treatment. Different superscripts letters $\left({ }^{a}\right.$, b) within rows indicate significant difference $(\mathrm{p}<0.05)$. 
The mycotoxin analyses conducted on 30 samples of domestic corn and 23 of imported corn are summarized in Table 5. No detectable levels of aflatoxins B2, G1 or G2, ochratoxin
A or T-2 and HT-2 toxins were found in any of the samples. Aflatoxin B1 was found in only 2 of the 23 imported corn samples, and in one of the 30 domestic samples.

Table 4. Percent fatty acid composition of domestic and imported corn samples.

\begin{tabular}{lccc}
\hline & & Corn origin & \\
\hline Fatty acid (\%) & Domestic & Imported & p \\
\hline C16:0 (palmitic) & $13.3 \pm 0.13^{\mathrm{a}}$ & $12.5 \pm 0.32^{\mathrm{b}}$ & 0.038 \\
C16:1 (palmitoleic) & $0.17 \pm 0.09^{\mathrm{a}}$ & $0.14 \pm 0.01^{\mathrm{a}}$ & $<.057$ \\
C18:0 (stearic) & $2.14 \pm 0.08^{\mathrm{a}}$ & $1.69 \pm 0.05^{\mathrm{b}}$ & $<0.001$ \\
C18:1 (oleic) & $31.3 \pm 0.73^{\mathrm{a}}$ & $27.7 \pm 0.20^{\mathrm{b}}$ & $<0.001$ \\
C18:2, n-6 (linoleic) & $50.6 \pm 0.69^{\mathrm{a}}$ & $55.5 \pm 0.34^{\mathrm{b}}$ & $<0.001$ \\
C18:3, n-3 ( $\alpha$-linolenic) & $0.94 \pm 0.02^{\mathrm{b}}$ & $1.12 \pm 0.01^{\mathrm{a}}$ & $<0.001$ \\
C20:0 (araquidic) & $0.57 \pm 0.03^{\mathrm{a}}$ & $0.33 \pm 0.01 \mathrm{~b}$ & $<0.001$ \\
C20:1 (eicosamonoenoic) & $0.31 \pm 0.01^{\mathrm{a}}$ & $0.26 \pm 0.00^{\mathrm{b}}$ & $<0.001$ \\
MUFAS & $31.8 \pm 0.74^{\mathrm{a}}$ & $28.1 \pm 0.21^{\mathrm{b}}$ & $<0.001$ \\
PUFAS & $51.5 \pm 0.70^{\mathrm{b}}$ & $56.6 \pm 0.34^{\mathrm{a}}$ & 0.006 \\
SFAS & $16.0 \pm 0.23^{\mathrm{a}}$ & $14.6 \pm 0.36^{\mathrm{b}}$ & $<0.001$ \\
n-6 & $50.6 \pm 0.76^{\mathrm{b}}$ & $55.5 \pm 0.28^{\mathrm{a}}$ & $<0.001$ \\
n-3 & $0.94 \pm 0.02^{\mathrm{a}}$ & $1.12 \pm 0.01^{\mathrm{a}}$ & 0.001 \\
n-6/n-3 & $53.8 \pm 1.09^{\mathrm{a}}$ & $49.5 \pm 0.67^{\mathrm{a}}$ & \\
\hline
\end{tabular}

Values are means \pm SEM of 10 samples. Different superscript letters $\left({ }^{a}, b\right)$ within rows indicate significant difference $(\mathrm{p}<0.05)$. MUFAS: monounsaturated fatty acids; PUFAS: polyunsaturated fatty acids; SFAS: saturated fatty acids; $\mathrm{n}-6$ : omega 6 fatty acids; n-3: omega 3 fatty acids.

Table 5. Mycotoxin contamination in domestic and imported corn samples.

\begin{tabular}{|c|c|c|c|c|c|c|c|c|}
\hline \multirow{2}{*}{ Mycotoxin } & \multirow{2}{*}{ Origin } & \multirow{2}{*}{$\begin{array}{c}\text { Number of } \\
\text { samples analyzed }\end{array}$} & \multirow{2}{*}{$\begin{array}{c}\text { Number of } \\
\text { positive samples }\end{array}$} & \multirow{2}{*}{$\begin{array}{c}\text { Percentage of } \\
\text { positive samples }\end{array}$} & Mean & Median & Minimum & Maximum \\
\hline & & & & & \multicolumn{4}{|c|}{$\mu \mathrm{g} / \mathrm{kg}$} \\
\hline \multirow[t]{2}{*}{ Aflatoxin B1 } & $\mathrm{D}$ & 30 & 1 & $3 \%$ & 2.8 & -- & 2.8 & 2.8 \\
\hline & I & 23 & 2 & $9 \%$ & 1.9 & 1.9 & 1.7 & 2.1 \\
\hline \multirow[t]{2}{*}{ Deoxynivalenol } & $\mathrm{D}$ & 30 & 0 & -- & -- & -- & -- & -- \\
\hline & I & 23 & 14 & $61 \%$ & 252 & 182 & 109 & 484 \\
\hline \multirow[t]{2}{*}{ Zearalenone } & $\mathrm{D}$ & 30 & 0 & -- & -- & -- & -- & -- \\
\hline & I & 23 & 10 & $43 \%$ & 53 & 55 & 28 & 88 \\
\hline \multirow[t]{2}{*}{ Fumonisin B1 } & $\mathrm{D}$ & 30 & 30 & $100 \%$ & 889 & 718 & 113 & 3,290 \\
\hline & I & 23 & 23 & $100 \%$ & 694 & 682 & 95 & 2,390 \\
\hline \multirow[t]{2}{*}{ Fumonisin B2 } & $\mathrm{D}$ & 30 & 27 & $90 \%$ & 283 & 252 & 61 & 1,200 \\
\hline & I & 23 & 18 & $78 \%$ & 184 & 173 & 58 & 596 \\
\hline \multirow[t]{2}{*}{ Fumonisin B3 } & $\mathrm{D}$ & 30 & 20 & $67 \%$ & 154 & 139 & 52 & 308 \\
\hline & I & 23 & 12 & $52 \%$ & 112 & 93 & 59 & 213 \\
\hline \multirow[t]{2}{*}{ Total fumonisins } & $\mathrm{D}$ & 30 & 30 & $100 \%$ & 1,196 & 1,099 & 52 & 4,798 \\
\hline & I & 23 & 23 & $100 \%$ & 864 & 559 & 95 & 3,199 \\
\hline
\end{tabular}

D: domestic corn; I: imported corn. 
Deoxinivalenol (DON) and zearalenone (ZEA) were only found in imported corn, in 61 (14 of 23 ) and $43 \%$ (10 of 23 ) of the samples, respectively. DON levels ranged from 109 to $484 \mathrm{ppb}$, while ZEA levels ranged from 28 to 88 ppb. Fumonisins B1, B2 and B3 were found in all samples, regardless of their origin. In locallygrown corn total fumonisin values ranged from 52 to $4,798 \mathrm{ppb}$, while in imported corn the values ranged from 95 to 3,199 $\mathrm{ppb}$.

\section{Discussion}

Corn is the main ingredient in complete poultry rations and therefore its quality plays an important role on the performance of laying hens and broiler chickens. Corn quality can be evaluated using different approaches, including the measurement of physicochemical variables or through biological assays. Corn quality can be measured using the subjective grading scale of the USDA-GIPSA (US1 to US5 and $\mathrm{SG}$ ), and the corn imported from the United States into Colombia is expected to be US2 grade (Vanegas-Angarita, 2019). In the present study, however, only one of the 21 samples of imported corn tested was found to correspond to US2 grade (10 were US3-5 grades and 10 were SG grade). Two different scenarios could potentially explain this particular finding. The first possibility is that even though US2 grade corn is being imported into the country, the percentage of broken grains and dust formation increases during transportation and handling (Győri, 2017; Hernández et al., 2009), leading to lower quality grains. The second possibility is that corn from lower quality than US2 is being imported, a scenario that could even have legal implications. In any case, the end result is the same for the local producer: imported grain corresponds to mostly US3 grade or lower. Another important aspect of corn quality is the presence of specific contaminants such as potentially harmful seeds. The high occurrence of soybeans found in the imported corn samples $(15 / 21)$ might represent a potential risk for poultry, due to the fact that raw soybeans are known to contain protease inhibitors, lectins, saponins, and other anti-nutritional compounds
(Perilla et al., 1997). Although no studies have been reported regarding the cause of contamination of corn lots with soybeans, it is most likely that this contamination occurs during transportation, when the ships are loaded with both types of seeds.

Regarding the proximal analyses, the differences found in dry matter and ash contents between domestic and imported corn could be attributed to differences in the quantity and type of fertilizers used, soil composition and/or environmental factors (Agama-Acevedo et al., 2011). In regard to carbohydrate content (expressed as nitrogenfree extract), it has been reported that it may vary according to the type, size and shape of the grain; however, previous studies have not found differences between crystalline corn (indurata variety, the corn grown in Colombia) and floury corn (indentata variety, corresponding to imported corn) (Tovar and Colonia, 2013). Nevetheless, in the present study imported corn had significantly higher carbohydrate content compared with locally produced corn. This difference could possibly be related to differences in endosperm composition since domestic corn contains both hard and soft endosperm, while imported varieties only contain soft endosperm (Tovar and Colonia, 2013). The protein levels found in the present study were similar for both domestic and imported corn and are in agreement with previously reported crude protein values (Tovar, 2008; Tovar and Colonia, 2013).

An accurate assessment of energy content available for the bird from dietary ingredients is important in poultry nutrition because modern strains of poultry demand a precisely defined energy to protein balance. In commercial poultry, the term metabolizable energy (ME) is used to express the fraction of ingested gross energy used by the bird, and the apparent ME (AME) is the difference between gross energy in the feed and gross energy from losses -such as those from digestivesecretions, intestinalflaking, bacteria and nitrogenous constituents from protein catabolism (Leeson and Summers, 2001). The present study compared the AME of one corn sample from domestic corn and one from imported corn. The 
results show a large difference in calculated AME values between imported and the domestic corn (319 kcal/kg higher in the latter). This difference in AME could be associated with lower crude fat content in imported corn (Table 3), which in turn might be the result of higher percentage of broken kernels and loss of corn germ (lesser quality). Another possible explanation for this difference could be the higher Fusarium mycotoxin content found in imported corn, which could be associated with fungal contamination in the field. Fungi secrete lipases that hydrolyze triglycerides to free fatty acids, which are then used as energy source by the fungus (Christensen and Kaufman, 1965). This fungal activity, therefore, decreases the energy content of the grain.

The fatty acid profile of the oil extracted from the two types of samples is consistent with previous studies (Carrillo et al., 2017; Györi, 2017). On the other hand, even though statistically significant differences were found in the present study, the overall fatty acid composition was similar between both types of corn. The predominant fatty acid in corn oil is linoleic (C18:2, n-6), followed by oleic (C18:1), palmitic (C14:0) and stearic (C18:0) acids (Györi, 2017). In a recent trial, the fatty acid profile of a corn sample included $52.7 \%$ linoleic acid, $29.7 \%$ oleic acid, $12.6 \%$ palmitic acid, and 2.0\% stearic acid (Carrillo et al., 2017). These percentages are similar to those found in the present study for both types of corn, although the imported had a higher percentage of linoleic acid than the domestic corn (55.5 and 50.6\%, respectively). Differences in fatty acid content can be attributed to changes in temperature before harvest (both heat or cold/freezing stress), which may decrease the content of specific fatty acids in the grain (Harwood, 1998).

As for mycotoxin content, a similar pattern of contamination with Aspergillus spp. mycotoxins (aflatoxins and ochratoxin A) was found in both samples. It should be noted, however, that corn samples used in this study represent only one crop year, and mycotoxin contamination may vary considerable as weather changes. Only two samples of imported and one of domestic corn contained AFB1 above the detection limit of the analytical technique $(1 \mu \mathrm{g} / \mathrm{kg})$, and in all cases the levels were below $3 \mu \mathrm{g} / \mathrm{kg}$, whereas none of the samples contained ochratoxin A. Maximum residue levels for total aflatoxins are 10 and $20 \mu \mathrm{g} / \mathrm{kg}$ in human foods and animal feeds, respectively (Regulation 4506/2013 of the Ministry of Health and Social Protection of Colombia, and NTC 535-1, 2014). The AFB1 levels found in the samples analyzed do not pose toxicological risk for domestic species, even to the most sensitive ones such as pigs and ducks. These results are in contrast with those of a previous study conducted in Colombia, in which 4 out of 33 corn samples contained AFB1, with $20 \mu \mathrm{g} / \mathrm{kg}$ average concentration (Díaz and Céspedes,1997), and underscore the need for continous monitoring of mycotoxins in corn. On the other hand, the lack of ochratoxin A contamination in both domestic and imported corn is consistent with previous studies conducted in Colombia (Céspedes, 1997), as well as in other countries of the American continent (Lee and Ryu, 2017). An interesting finding of the present study was the absence of the fusariotoxins DON and ZEA in domestic samples, which were present in 61 and $43 \%$ of the imported corn samples, respectively. These results agree with several studies conducted in the United States, in which high prevalence of DON and ZEA has been reported (Lee and Ryu, 2017). The DON and ZEA levels found pose no risk to chickens or hens (Diaz, 2020), however, they could potentially have adverse effects on health and productive performance of pigs. In regard to the fusariotoxins T-2 and HT-2, no detectable levels were found in domestic or imported corn. These results agree with recent studies (Lee and Ryu, 2017) and are the basis for the decision taken by the European Union about not regulating these toxins in human food or animal feed. The fusariotoxins known as fumonisins were the only mycotoxins found in all samples analyzed. These results are not surprising since fumonisins are commonly found in corn (Diaz, 2020); they are produced by a fungus that is a normal inhabitant -an endophyte- of the grain (Fusarium verticillioides). The importance of fumonisins lies not on their presence, but on their actual concentrations. In this regard, 
the levels found in some domestic and foreign samples were above the recommended levels for domestic animals such as horses and rabbits, for which no more than $1 \mathrm{mg}$ of total fumonisins $/ \mathrm{kg}$ is recommended in a complete $\operatorname{diet}$ (FDA, 2001).

In conclusion, the results of the present study show that corn imported from the US tends to have a higher content of broken grains, which might result from increased grain deterioration due to transport and loading and unloading processes. The dry matter content of imported corn was significantly lower than that in domestic corn, and resulted in numerically lower crude fat, which could be the reason for the lower AME value found in the imported corn sample, compared with the domestic one. In addition to these findings, the occurrence of soybean seeds in $71 \%$ of the imported corn samples may represent a potential hazard due to protease inhibitors and other anti-nutritional compounds present in raw soybeans. Further, imported corn samples contained fusariotoxins commonly found in North America that were not detected in domestic corn. Taken together, these findings suggest that domestic corn has better nutritional qualities and is safer in terms of mycotoxin and foreign seed contamination compared to imported corn. More studies are needed to investigate if these findings are consistent over time, and to determine if mycotoxin concentrations may vary depending on sampling times. Further studies are needed to determine if the differences observed in the present study result in differences in productive performance of poulty when these types of corn are used to formulate complete diets.

\section{Declarations}

\section{Funding}

This work was supported by Federación Nacional de Cultivadores de Cereales y Leguminosas (FENALCE), Colombia. These results are part of a research project entitled "Evaluación nutricional y biológica de maíz nacional e importado en Colombia".

\section{Conflict of interest}

The authors declare they have no conflicts of interest with regard to the work presented in this report.

\section{Author contributions}

Yandy J. Aguillón-Páez: processed the samples, conducted the chicken trial, collected the raw data and drafted the article. Gonzalo J. Diaz: designed the study, helped with the data analysis and revised the article draft. Liliana Betancourt: designed the chicken trial and revised the article draft.

\section{References}

Agama-Acevedo E, Salinas-Moreno Y, Pacheco-Vargas G, Bello-Pérez LA. Características físicas y químicas de dos razas de maíz azul: morfología del almidón. Rev Mex Cienc Pecu 2011; 2(3):317-329. URL: http://www.scielo.org.mx/scielo.php?script=sci arttext\&pid=S2007-09342011000300002\&lng $=$ $\underline{\text { s\&tlng}=\mathrm{es}}$

Aguillón-Páez Y, Romero L, Diaz G. Effect of full-fat sunflower or flaxseed seeds dietary inclusion on performance, egg yolk fatty acid profile and egg quality in laying hens. Animal Nutrition 2020; 6(2):179-184. DOI: https://doi.org/10.1016/j.aninu.2019.12.005

AOAC. Association of Official Analytical Chemists. Official Methods of Analyses. 2006. $18^{\text {th }}$ Ed. Gaithers burg MD, USA.

Carrillo W, Carpio C, Morales D, Vilcacundo E, Alvarez M, Silva M. Content of fatty acids in corn (Zea mays L.) oil from Ecuador. Asian J Pharm Clin Res 2017; 10(8):150-153. DOI: http://dx.doi.org/10.22159/ajpcr.2017.v10i8.18786

Céspedes A. Desarrollo y estandarización de tres técnicas analíticas por cromatografía de alta eficiencia (HPLC) y determinación de los niveles de con aflatoxinas, zearalenona y ocratoxina A en materias primas y alimento terminado empleados para la nutrición de aves y cerdos en Colombia. 
Trabajo de grado para optar por el título de Magister en Ciencias, Postgrado en Salud y Producción Animal 1997. Facultad de Medicina Veterinaria y de Zootecnia, Universidad Nacional de Colombia.

Christensen CM, Kaufmann HH. Deterioration of stored grains by fungi. Annu Rev Phytopathol 1965; 3(1):69-84.

CIMMYT. Centro internacional de mejoramiento de maíz y trigo. Calidad de grano para técnicos postcosecha. Laboratorio de calidad nutricional de maíz. México D.F. 2016; Pág 1-10.

Diaz G. Toxicología de la micotoxinas y sus efectos en avicultura comercial. Editorial Acribia. Zaragoza (España); 2020.

Diaz G, Céspedes A. Natural occurrence of zeralenone in feeds and feedstuffs used in poultry and pig nutrition in Colombia. Mycotoxin Res 1997; 13(2):81-87. DOI: https://doi.org/10.1007/BF02945070

FDA U. Guidance for Industry on Fumonisin Levels in Human Foods and Animal Feeds. Dockets Management Branch (HFA-305). Rockville, MD: US Food and Drug Administration. 2001. URL: https://www.fda.gov/regulatory-information/ search-fda-guidance-documents/guidanceindustry-fumonisin-levels-human-foods-andanimal-feeds

FENALCE. Federación Nacional de Cultivadores de Cereales y Leguminosas. Comunicado de los agricultores nacionales de maíz. [access date: November 2019] URL: https://www.fenalce.org/alfa/pg.php?pa $=60$

Győri Z. Corn: Grain-Quality Characteristics and Management of Quality Requirements. In: Wrigley C, Batey I, Miskelly D, editors. Cereal Grains: Assessing and Managing Quality. $2^{\text {nd }} \mathrm{ed}$. Woodhead Publishing; 2017. p. 257-290. DOI: https://doi.org/10.1016/B978-0-08-100719-8.00011-5

Harwood J. 13 Environmental effects on plant lipid biochemistry. In: Harwood JL, editor. Plant lipid biosynthesis: fundamentals and agricultural applications. Vol 67. Cambridge University press; 1998. p. 305.

Rev Colomb Cienc Pecu 2022; 35(1, Jan-Mar):36-48 https://doi.org/10.17533/udea.rccp.v35n1a04
Hernández C, Rodríguez Y, Niño Z. Efecto del almacenamiento de granos de maiz (Zea mays) sobre la calidad del aceite extraido. Inf. Tecnol 2009; 20(4):21-30. DOI: http://dx.doi.org/10.4067/S0718-07642009000400004

LeeHJ,RyuD.Worldwideoccurrenceofmycotoxins in cereals and cereal-derived food products: public health perspectives of their co-occurrence. Agric Food Chem 2017; 65(33):7034-7051. DOI: https://doi.org/10.1021/acs.jafc.6b04847

Leeson S, Summers J. Scott's. Nutrition of the chicken. 4rd edition. University Books, Guelph, Ontario, Canada. 2001. p. 42.

Martos P, Thompson W, Diaz G. Multiresidue mycotoxin analysis in wheat, barley, oats, rye and maize grain by high-performance liquid chromatography-tandem mass spectrometry. World Mycotoxin J 2010; 3(3):205-223. DOI: https://doi.org/10.3920/WMJ2010.1212

Micolucci V. Producción mundial de maíz 2019/2020. Food news. Noticias diarias de la industria de alimentos y bebidas América Latina. [access date: January 2019] URL: https://www.foodnewslatam.com/paises/89peru/9203-producci\%C3\%B3n-mundial-dema\%C3\%ADz-2019-2020.html

Ministerio de salud y protección social. (2013). Niveles máximos de contaminantes en los alimentos destinados al consumo humano. Resolución 4506 del 30 de octubre de 2013.

National Research Council. Nutrient requirements of poultry (9th rev.), Natl. Acad. Press, Washington, D.C 1994. DOI: https://doi.org/10.17226/2114

Norma Técnica Colombiana. NTC 535-1. 2014. Alimento para animales maíz. Editada por el Instituto Colombiano de Normas Técnicas y Certificación (ICONTEC). Apartado 14237. Bogotá, D.C. Editada 2014-11-06.

Norma Técnica Colombiana. NTC 6027. 2013. Determinación de toxinas T-2 y HT-2 en granos de cereal mediante limpieza por inmunoafinidad y cromatografía líquida con detección de fluorescencia. Editada por el 
Instituto Colombiano de Normas Técnicas y Certificación (ICONTEC). Apartado 14237. Bogotá, D.C. Editada 2013-11-27.

Norma Técnica Colombiana. NTC 5961. 2012. Determinación de deoxinivalenol (DON) en harina de trigo blanca, harina de trigo integral y salvado de trigo mediante cromatografía líquida de alta eficiencia / extracción de fase sólida. Editada por el Instituto Colombiano de Normas Técnicas y Certificación (ICONTEC). Apartado 14237. Bogotá, D.C. Editada 2012-12-21.

Norma Técnica Colombiana. NTC 5472. 2007. Determinación de ocratoxina $\mathrm{A}$ en cereales y sus derivados por cromatografía líquida de alta eficiencia, HPLC. Editada por el Instituto Colombiano de Normas Técnicas y Certificación (ICONTEC). Apartado 14237. Bogotá, D.C. Editada 2007-03-28.

Norma Técnica Colombiana. NTC 4881. 2000. Método de análisis de Zearalenona de ocurrencia natural. Editada por el Instituto Colombiano de Normas Técnicas y Certificación (ICONTEC). Apartado 14237. Bogotá, D.C.

Norma Técnica Colombiana. NTC 1232. 1996. Método de análisis de aflatoxinas de ocurrencia natural (B1, B2, G1 y G2). Editada por el Instituto Colombiano de Normas Técnicas y Certificación (ICONTEC). Apartado 14237. Bogotá, D.C. Primera actualización 2001-09-11.

Perilla NS, Cruz MP, De Belalcazar F, Diaz, GJ.. Effect of temperature of wet extrusion on the nutritional value of full $\square$ fat soya beans for broiler chickens. Br Poult Sci 1997; 38(4):412-416. DOI: https://doi.org/10.1080/00071669708418011
Sakomura N, Rostagno H. Métodos de pesquisa emnutriçao de monogastricos. Metodologias para avaliar o conteúdode energía dos alimentos. $2^{\text {a }}$ ed. Jaboticabal:Funep. Universidade Federal de Viçosa. 2016. P.53.

Statistix 9. (2008). User's Manual, Analytical software. Tallahassee, Florida.

Tovar CDG, Colonia BSO. Producción y procesamiento del maíz en Colombia. Revista Guillermo de Ockham 2013; 11(1):97-110. DOI: https://doi.org/10.21500/22563202.604

Tovar, T. (2008). Caracterización Morfológica y termica del almidon de Maíz (Zea mays L) obtenido por diferentes metodos de aislamiento. Universidad autónoma del estado de Hidalgo. Tesis pregrado. Pachuca de Soto, Hidalgo.

USDA-GIPSA. United States Standards for Corn. (1996). USDA Grain Inspection, Packers and Stockyards Administration (GIPSA). [access date: December 2019] URL: http:/www.gipsa.usda.gov/fgis/standards/810corn. pdf

Vanegas-Angarita, H. CEO Federación Nacional de Cultivadores de Cereales y Leguminosas. Personal communication. 2019.

Williams CH, David DJ, Iismaa O. The determination of chromic oxide in faeces samples by atomic absorption spectrophotometry. J Agric Sci 1962; 59(3):381-385. DOI: https://doi.org/10.1017/S002185960001546X 